\title{
在日ブラジル人生徒のインターネット依存度に関する 調査一質問紙を用いた横断研究
}

Internet Addiction among Brazilian Students in Japan — A Questionnaire-based Cross-sectional Study

\section{青木 大 祐 ${ }^{11}$ 金子 惊 ${ }^{2}$ 井上真智子 ${ }^{2}$}

Daisuke Aoki ${ }^{1)}$, Makoto Kaneko ${ }^{2)}$, Machiko Inoue ${ }^{2)}$

\begin{abstract}
要 旨
目的：青少年のインターネット依存傾向が問題となっているが社会的マイノリティに関する現状は不明であ る. 本研究では, 在日ブラジル人生徒の現状を調査する.

方法 : A 市在住ブラジル人生徒 342 人にポルトガル語の質問紙で, インターネット依存度 (以下 IAT), ネット 利用時間, 睡眠, うつ傾向（PHQ2）を評価した. $\chi^{2}$ 検定，ロジスティック回帰分析を用いた.

結果 : 回答率 $65 \%$ (222 人). IAT50 点以上と相関したのは睡眠 7.5 時間以下 (オッズ比 : $0.38,95 \%$ 信頼区間 : 0.21-0.68), 平日のネット利用 4 時間以上 (2.6, 1.4-4.8), PHQ2 が 3 点以上 $(6.2,3.3-11.5)$ だった. 多変量解析 でも PHQ2 と平日の利用時間は有意だった.

結論：A市在住ブラジル人生徒のインターネット依存度には, 平日のネット利用時間とうつ傾向が関連してい た.
\end{abstract}

\footnotetext{
Abstract

Introduction: To elucidate the issues surrounding adolescents' Internet use in social minority groups, this study investigated the current situation of Internet addiction among Brazilian students who live in A city in Japan.

Methods: The participants were 342 local Brazilian students attending international schools. A cross-sectional study using a self-administered questionnaire in Brazilian-Portuguese was conducted. As a primary outcome, we used Young's Internet Addiction Test (IAT) to evaluate the level of self-reported Internet addiction. Social demographics (i.e. age, sex, etc. ), lifestyle (i.e. the time for Internet use, sleeping hours, etc. ), and depressive tendency (Patient Health Questionnaire 2, PHQ2) were also assessed. The $\chi$-square test and logistic regression analysis were used for analysis.

Results: The response rate was $65 \%$ (222; 111 males and 111 females). Factors related to an IAT score of 50 or higher were sleeping hours ( $<7.5$ hours) (OR: 0.38 , 95\%CI: $0.21-0.68$ ), the time for Internet use ( $\geq 4$ hours) (2.6, 1.4-4.8), and PHQ2 score ( $\geq 3)(6.2,3.3-11.5)$. On logistic regression analysis, an IAT score $\geq 50$ was positively associated with the time for Internet use and PHQ2 score $\geq 3$.

Conclusion: The self-report of high Internet addiction among Brazilian students in A city in Japan was significantly related to the time for Internet use and depressive tendency.

Keywords : 在日ブラジル人 (Brazilian population in Japan), インターネット依存 (Internet Addiction), 青少年 (adolescents)，インターネット利用時間（time for Internet use）うつ傾向（depression）
}

1)浜松医科大学医学部医学科

2) 浜松医科大学地域家庭医療学講座

著者連絡先：井上真智子 浜松医科大学地域家庭医療学講座 [ $\overline{\mathrm{T}} 431-3192$ 静岡県浜松市東区半田山一丁目 20 番 1 号 $]$

email:machiko@hama-med.ac.jp

(受付日：2019年 9 月 9 日，採用日：2020 年 3 月 11 日)

(C)2020 日本プライマリ・ケア連合学会 


\section{はじめに}

近年インターネットが急速に普及し我々の生活に密 接に関わるものとなった.内閣府による平成 30 年度の 調査では, 小学生のインターネット利用は $85.6 \%$, 中学 生は $95.1 \%$, 高校生は $99.0 \%$ にのぼる ${ }^{1)}$.一方で, イン ターネットの使用に歯止めがかからず，日常生活に問 題をきたすインターネット依存傾向が問題になってい る. 平成 28 年の総務省の報告によるとインターネット 依存傾向の高い生徒は中学生で $5.7 \%$, 高校生で $4.6 \%$ であった22. インターネット依存傾向に関する問題は, アメリカ精神医学会の精神疾患の分類と骖断の手引 （DSM-5）では記載がなく疾患としての定義に議論の 余地があるものの ${ }^{3)}$, 広く研究が進められている. 中高 生から大学生は, 依存に陥りやすい傾向が指摘されて いる他 ${ }^{4,5}$, インターネット依存傾向の高い生徒は, 学 力の低下や不登校, 睡眠不足や視力低下といった因子 や，自尊心の低下やうつ，自殺念慮と自殺企図といっ た精神症状との関連も指摘されており, 現状把握を目 的とした調查は急務である る $^{3,6 \sim 11)}$.

上記は社会的多数派に属する集団についての報告だ が, 社会的マイノリティである移民にとって,インター ネットは文化的相違への逃避や対処手段, またアイデ ンティティの形成手段として大きな役割を持つ可能性 が指摘されている ${ }^{12}$. また移民は, インターネット依存 傾向になるリスクが先行研究で示唆されており ${ }^{13.14}$, 在 日外国人生徒に扔いてもインターネット依存傾向に至 るリスクが高いのではないかという仮説を我々は有し ている．青少年の移民を対象とした先行研究 ${ }^{14)}$ は薬物 やギャンブルを含めた依存症について包括的に評価し た研究であり, インターネット依存傾向にある移民が どの様な背景因子や生活習慣, 精神症状と関連するか については不明である.

プライマリ・ケア領域の役割として, 平等な医療提 供 ${ }^{15)}$ や未分化な健康問題への対応 ${ }^{16)}$ がある. 在留外国 人数が過去最高 $(2019$ 年 6 月末時点) を記録し多様化 が進む中で ${ }^{17)}$, 在日外国人へのプライマリ・ケア提供 の機会が増えると予想される。 またインターネット依 存傾向に関連する睡眠障害や不登校といった未分化な 健康問題へ対応するために, プライマリ・ケア領域の 医療従事者が関与する可能性がある。

以上より本研究では社会的マイノリティである在日 外国人生徒のインターネット利用状況やインターネッ 卜依存傾向を明らかにし, 背景因子, 生活習慣, 精神 症状との関連を把握することを目的とした.

\section{方 法}

\section{(1) 調查対象}

静岡県は在日外国人の割合が比較的高い都道府県で あるが18)，その中でもブラジル人が県内在住外国人の $31.7 \%$ を占め, 割合が最も高い国.

本研究では, 2018 年 9 月に静岡県 $\mathrm{A}$ 市の外国人学 校に通学していた小学校 5 年生から高校 3 年生ブラジ ル人生徒で, 静岡県 A 市市役所が把握している外国人 学校 3 校の中で, 承諾を得た 2 校に通学する全 342 人 を対象とした ( $\mathrm{X}$ 校 : 175 人, $\mathrm{Y}$ 校 : 167 人).

外国人学校とは外国人児童生徒を対象とする教育施 設とされる，その中には，国際的な評価団体や，学校 教育法に基づいて都道府県知事から認可を受けている もの, 日本の高等学校に相当する学校の課程と同等の 課程を有するものが含まれる20. 本研究の対象として 選定した外国人学校は, 学校教育にポルトガル語が主 に使用され，文部科学省より指定を受けた学校とし た ${ }^{211}$. 生徒の出生地による国籍が日本かブラジルかは 問わない.

先行文献ではほぼ全ての授業がポルトガル語で行わ れており, 日本語の授業は週 1-2 時間である22).ブラジ ル国籍のブラジル人がほとんどを占め, 多くのブラジ ル人がポルトガル語の方が得意とする傾向も示されて いる22). 本調查でもポルトガル語を主に使用する生徒 を対象とすることを想定した。

\section{(2) 研究デザイン}

本研究は探索的横断研究として, ポルトガル語での 無記名自記式質問紙調査を実施した.

\section{(3) 研究手続き}

学校長へ調查の目的, 説明文書, 質問紙, 調查手続 きについて説明し, 調查実施への承認を得た. 小中学 生へは説明文書と質問紙を学校で配布し教師からの説 明の後, 保護者からの同意を得て自宅で回答しても らった，高校生へは説明文書と質問紙を配布し，生徒 に直接説明を行った上で本人からの同意を得て, 学校 で回答してもらった，回答は自由意思によることを説 明した。本研究は浜松医科大学臨床研究倫理委員会に て承認を得た上で害施した（18-141 号).

\section{（4）調査項目}

\section{・主要評価項目}

インターネット依存度の評価には, 過去の日本やブ ラジルで研究実績2.3)を元にYoung's Internet Addiction Test (以下 IAT) のポルトガル語版を用いた23.24). 質問は 20 項目で構成され，「全くない (1 点)」から 「いつもある (5 点)」を選択して合計 $20-100$ 点まで配 
点する. 点数が高いほどインターネット依存傾向が高 いと評価する。

・副次評価項目

社会的人口統計因子, インターネット利用状況, 生 活習慣，うつ傾向を評価した．各項目はインターネッ 卜依存症の先行調査や, 在日ブラジル人を対象とした 精神医学的研究の先行調査を参考に設定した.

(a) 社会的人口統計因子 1 , 7.9.25)

- 年歯令

- 性別

・兄弟の有無

- 国籍

- 日本滞在年数

(0.5 年未満, 0.5 年- 1 年未満, 1 年-3 年未満, 3 年- 5 年未満, 5 年以上)

・日系世代

(非日系, 1 世, 2 世, 3 世, その他)

（b）インターネット利用状況 1,2.8.9.26)

・平日と休日のインターネット利用時間

(全く使わない, 0.5 時間未満, 0.5 時間-1 時間未満, 1 時間-2 時間未満, 2 時間-3 時間未満, 3 時間-4 時間 未満, 4 時間以上)

・昨年からのインターネット利用時間の変化

(増えている, 変わらない, 減っている)

・インターネット利用目的

（ゲーム, 情報検索, 音楽・動画サイト, メールや チャット, Social Networking Service (以下 SNS), 掲示板, 無料通話, その他)

・インターネット利用機器

（スマートフォン, パソコン, タブレット, 音楽プレー ヤー，ゲーム機，携帯ゲーム，その他）

(c) 生活習慣 ${ }^{2}$. 9.27)

・睡眠時間（就寝時間，起床時間）

- 学外学習の所属 (有無)

・クラブ活動への所属 (有無)

(d) うつ傾向

精神状態に関して評価するために, Patient Health Questionnaire 2(以下 PHQ2) のポルトガル語版を用い た ${ }^{28)}$. 2つの質問に対して,「最近 2 週間に全くない $(0$ 点)」から「最近 2 週間にほほ毎日 (3 点)」の合計 6 点を配点し, 得点が高い程うつ傾向が高いとする. $\mathrm{PHQ} 2$ が 3 点以上をうつ傾向があるとした ${ }^{29,30)}$.

\section{統計解析}

日本人およびブラジル本国のブラジル人におけるイ
ンターネット依存傾向の結果と比較する為, 先行研究 で用いられている区分とあわせ，日本人生徒との比較 は 3 群に ${ }^{2.23)}$, ブラジル人生徒の比較は IATを 50 点以 上/未満の 2 群に分けて行った ${ }^{3)}$.

インターネット依存度に影響のある因子の検討を行 うために, IATを 50 点以上/未満の 2 群に分けた従属 変数, $\mathrm{PHQ} 2$ を含む副次評価項目を独立変数とした $\chi^{2}$ 検定及び単変量ロジスティック回帰分析を行った.

IAT のカットオフスコアは研究によって異なり, 40 点以上および 50 点以上が頻繁に使用される. 本研究で は 50 点を用いた文献 ${ }^{31 ~ 33)}$, ブラジル国内の先行研究3), カットオフスコアを平均点以上にする必要性を示唆す る文献 ${ }^{34)}$ を参照して 50 点を用いた。

また, PHQ2 と IAT スコアの相関をみるため, IAT (50 点以上/未満) を従属変数とし, PHQ2（3 点以上/ 未満）と背景因子を独立変数とした多変量ロジス ティック回帰分析を行った。

モデル 1 では基本属性に加え, IAT ( 2 群) の単変量 解析にて $P<0.30$ であった因子を多変量調節因子とし て投入した（平日のインターネット利用時間，性別， 年齢, 睡眠時間, 兄弟の有無, 昨年からの利用時間の 変化, クラブ活動).

モデル 2 では基本属性と IAT (2 群)の単変量解析に て $P<0.05$ であった因子を多変量調節因子として投入 した（平日のインターネット利用時間, 性別, 年齢, 睡眠時間).モデル適合度判定には Hosmer-Lemeshow 検定を用いた。

解析には統計ソフト IBM SPSS statistics（ver24）を 用いた。統計学的有意水準は両側 $P<0.05$ とした.

\section{結 果}

（1）対象者の基本属性とインターネット利用状況 (表 1)

対象者 342 人の内 222 人（回答率 $65 \%$ : 男 111 人, 女 111 人）からの回答を取得した. 平均年齢は $14.9 \pm$ 2.3 歳であった。滞在平均年数は 5 年以下が $38.5 \%$, 日 系世代 3 世以上が $87.8 \%$, 国籍はブラジル国籍が $89.6 \%$ を占めた。

インターネット利用に関してスマートフォンの使用 率は $81.1 \%$ を占めた。利用目的は「動画・音楽サイト」 の使用が $84.7 \%$, 次いで SNS の使用が $74.3 \%$ と高かっ た。

インターネットの利用時間に関して，1日 4 時間以 上の生徒が平日で $57.2 \%$, 休日で $68.5 \%$ であり, 休日の 方が高い割合で長時間使用していることが分かった 
表 1 対象者属性

\begin{tabular}{|c|c|c|c|c|c|c|c|}
\hline \multicolumn{8}{|c|}{$N=222$} \\
\hline \multicolumn{2}{|r|}{ 度数 } & $N$ & $\%$ & \multicolumn{2}{|r|}{ 度数 } & $N$ & $\%$ \\
\hline \multicolumn{4}{|l|}{ 対象者基本属性 } & \multicolumn{4}{|c|}{ インターネット利用状況 } \\
\hline \multirow[t]{4}{*}{ 年齢（歳） } & 平均値：14.9土2.3\% & & & \multirow{7}{*}{$\begin{array}{l}\text { 平日のインター } \\
\text { ネット利用時間 } \\
\text { (時間) }\end{array}$} & 全く使用しない & 8 & 1.4 \\
\hline & 15 歳未満 & 71 & 32.0 & & 0.5 時間未満 & 15 & 1.8 \\
\hline & 15 歳以上 & 136 & 61.3 & & 0.5 時間 - 1 時間 & 35 & 2.7 \\
\hline & 欠損値 & 15 & & & 1 時間 -2 時間 & 18 & 8.1 \\
\hline \multirow[t]{3}{*}{ 性別 } & 男性 & 111 & 50.0 & & 2 時間 -3 時間 & 27 & 12.2 \\
\hline & 女性 & 111 & 50.0 & & 3 時間 -4 時間 & 37 & 16.7 \\
\hline & 欠損値 & 0 & & & 4 時間以上 & 127 & 57.2 \\
\hline \multirow{6}{*}{$\begin{array}{l}\text { 日本帯在年数 } \\
\text { (年) }\end{array}$} & 0.5 年末満 & 8 & 3.6 & \multirow{6}{*}{$\begin{array}{l}\text { 休日のインター } \\
\text { ネット利用時間 } \\
\text { (時間) }\end{array}$} & 欠損値 & 0 & \\
\hline & 0.5 年 -1 年 & 15 & 6.8 & & 全く使用しない & 0 & 0.0 \\
\hline & 1 年 -3 年 & 35 & 15.8 & & 0.5 時間未満 & 1 & 0.5 \\
\hline & 3 年 -5 年 & 26 & 11.7 & & 0.5 時間 -1 時間 & 5 & 2.3 \\
\hline & 5 年以上 & 134 & 60.4 & & 1 時間 -2 時間 & 12 & 5.4 \\
\hline & 欠損値 & 4 & & & 2 時間 -3 時間 & 18 & 8.1 \\
\hline \multirow[t]{3}{*}{ 国籍 } & ブラジル & 199 & 89.6 & & 3 時間 -4 時間 & 33 & 14.9 \\
\hline & 日本 & 3 & 1.4 & & 4 時間以上 & 152 & 68.5 \\
\hline & 欠損値 & 20 & & & 欠損値 & 1 & \\
\hline \multirow[t]{3}{*}{ 兄弟の有無 } & 有 & 140 & 63.1 & \multirow{3}{*}{$\begin{array}{l}1 \text { 年前との利用 } \\
\text { 時間の変化 }\end{array}$} & 増加 & 74 & 33.3 \\
\hline & 無 & 82 & 36.9 & & 変わらない & 97 & 43.7 \\
\hline & 欠損値 & 0 & & & 減少 & 49 & 22.1 \\
\hline \multirow[t]{14}{*}{ 日系世代（世） } & $1-2 世$ & 16 & 7.2 & \multirow{5}{*}{$\begin{array}{l}\text { インターネット } \\
\text { 使用機器※※ }\end{array}$} & 欠損値 & 2 & \\
\hline & $3 世$ & 99 & 44.6 & & スマートフォン & 180 & 81.1 \\
\hline & 4 世以上 & 96 & 43.2 & & PC & 103 & 46.4 \\
\hline & なし & 3 & 1.4 & & タブレット & 71 & 32.0 \\
\hline & \multirow[t]{9}{*}{ 欠損値 } & \multirow[t]{9}{*}{8} & & & 携帯 & 68 & 30.6 \\
\hline & & & & & ゲーム & 50 & 22.6 \\
\hline & & & & & 音楽プレーヤー & 10 & 4.6 \\
\hline & & & & 接続サイト※※ & 動画音楽サイト & 188 & 84.7 \\
\hline & & & & & SNS & 165 & 74.3 \\
\hline & & & & & 検索 & 135 & 60.8 \\
\hline & & & & & ゲーム & 132 & 59.5 \\
\hline & & & & & メール・チャット & 126 & 56.8 \\
\hline & & & & & 掲示板 & 12 & 5.4 \\
\hline & 度数 & $N$ & $\%$ & \multicolumn{2}{|c|}{ 度数 } & $N$ & $\%$ \\
\hline \multicolumn{4}{|l|}{ 生活習慣について } & \multicolumn{4}{|l|}{ うつ傾向 } \\
\hline \multirow[t]{4}{*}{ 睡眠時間 (時間) } & 平均值：7.47士1.49\% & & & PHQ2 (点) & 平均値：1.96士1.81\% & & \\
\hline & 7.5 時間以上 & 100 & 45.0 & & 3 点以上 & 72 & 67.6 \\
\hline & 7.5 時間未満 & 118 & 53.2 & & 3 点未満 & 150 & 32.4 \\
\hline & 欠損値 & 4 & & & 欠損値 & 0 & \\
\hline クラブ活動の & はい & 88 & 39.6 & & & & \\
\hline 所属 & いいえ & 134 & 60.4 & & & & \\
\hline & 欠損値 & 0 & & & & & \\
\hline 学外学習 & はい & 93 & 41.9 & & & & \\
\hline & いいえ & 128 & 57.7 & & & & \\
\hline & 欠損値 & 1 & & & & & \\
\hline
\end{tabular}

SNS : Social Networking Service

PHQ2 : Patient Health Questionnaire 2

※平均値士標準偏差 (standard deviation, $S D$ )

※*複数回答可 
表 2 Young's Internet Addiction Test による分類と日本人生徒との比較 $N=222$

\begin{tabular}{|c|c|c|c|c|c|c|c|c|}
\hline & & & & & & & T※ & \\
\hline & 目 & & $N$ & & $\begin{array}{c}\text { 依存傾向 } \\
\text { [低」 }\end{array}$ & $\begin{array}{c}\text { 依存傾向 } \\
\lceil\text { 中」 }\end{array}$ & $\begin{array}{c}\text { 依存傾向 } \\
\text { 「高」 }\end{array}$ & 全体平均 \\
\hline & & & & $\begin{array}{l}N \\
\%\end{array}$ & $\begin{array}{c}94 \\
923 \%\end{array}$ & $\begin{array}{c}114 \\
514 \%\end{array}$ & $\begin{array}{c}14 \\
63 \%\end{array}$ & \\
\hline & & 全体 & 222 & $\frac{\%}{\text { 平均 }+\mathrm{s} n}$ & $\begin{array}{c}42.3 \% \\
318+52\end{array}$ & $51.4 \%$ & $6.3 \%$ & \\
\hline 本調查 & ブラジル人 & & & $\frac{N}{N}$ & $\frac{31.8 \pm 5.2}{51}$ & $\frac{52.2 \pm 8.8}{70}$ & $\frac{18.4 \pm 9.6}{10}$ & $45.2 \pm 15.1$ \\
\hline & & 高校生 & 131 & $\%$ & $38.9 \%$ & $53.4 \%$ & $7.6 \%$ & \\
\hline & & & & 平均 $\pm S D$ & $33.4 \pm 4.1$ & $52.2 \pm 8.7$ & $77.5 \pm 9.9$ & $46.8 \pm 14.6$ \\
\hline & & 中学牛 2) & 9475 & N & 4314 & 4625 & 536 & \\
\hline & 日大1 & & & $\%$ & $45.5 \%$ & $48.8 \%$ & $5.7 \%$ & \\
\hline & 中本人 & 高校生 9) & 14071 & $N$ & 5658 & 7768 & 645 & \\
\hline & & 回仅工 & $140 / 1$ & $\%$ & $55.2 \%$ & $40.2 \%$ & $4.6 \%$ & \\
\hline
\end{tabular}

IAT : Young's Internet Addiction Test

$S D:$ standard deviation

※20-39点を依存傾向「低」40-69点を依存傾向「中」70-100 点を依存傾向「高」と分類 2, 9, 23)

(表 1，3）. 1 年前と比較して利用時間が増えたと答 えた生徒は $33.3 \%$ であった。

先行研究において日本人青少年 (小学生〜高校生)で は $24.6 \%$ (平成 30 年) であったのに対して，本調査対 象である在日ブラジル人生徒では高かった。また高校 生同士の比較でも日本人高校生の $39.4 \%$ (平成 30 年)に対して, 本研究では平日 $66.4 \%$, 休日 $74.0 \%$ であ り在日ブラジル人生徒の方が高い事が分かった ${ }^{11}$.

\section{（2）インターネット依存傾向（表 2）}

IAT の平均值は $45.2 \pm 15.1$ 点であった. IATの 3 群による群分けでは, IAT が 70 点以上でインター ネット依存傾向が「高」とスクリーニングされる比率 は $6.3 \%$, 高校生では $7.6 \%$ を占めた.

これまでの大規模調查では, 70 点以上のインター ネット依存傾向「高」は日本人高校生で $4.6 \%$ (平成 26 年), 中学生では $5.7 \%$ (平成 28 年) であった ${ }^{2.9)}$. 本研 究では依存傾向「高」は全体で $6.3 \%$, 高校生では 7.6\% であり，同等以上といえる，また，ブラジル本国に住 むブラジル人生徒では，50 点以上の者が $21.3 \%$ (平成 29 年) であったのに対し, 本研究では $32.5 \%$ と高かっ だ).

$\chi^{2}$ 検定より, IAT（2 群）は「睡眠時間（7.5 時間未 満)」が短い程高く (Odds Ratio：OR=0.38, 95\% Confidence Interval : CI=0.21-0.68), 「平日のインターネッ 卜利用時間 (4 時間以上) $」(\mathrm{OR}=2.60,95 \% \mathrm{CI}=1.42-4.77)$ や「休日のインターネット利用時間 (4 時間以上)」(OR $=2.47,95 \% \mathrm{CI}=1.26-4.83)$ が長い程高かった。 また「う つ傾向（3 点以上）」が高い程 IAT は高くなった（OR
$=6.19, \quad 95 \% \mathrm{CI}=3.32-11.51)$.

\section{(3) 多変量解析}

多変量ロジスティック回帰分析（表 3）では，モデ ル 1 において, IAT (50 点以上) と関連する因子とし て PHQ2（3 点以上）が確認された $(\mathrm{OR}=7.00,95 \% \mathrm{CI}$ $=3.42$-14.29). Hosmer-Lemeshow 検定結果は $P=0.603$ で適合していた，モデル 2 では, IAT（50 点以上）と 関連する因子に, $\mathrm{PHQ} 2$ (3 点以上) $(\mathrm{OR}=6.15,95 \% \mathrm{CI}$ $=3.12-12.11$, 平日のインターネット利用時間 (4 時間 以上) $(\mathrm{OR}=2.07,95 \% \mathrm{CI}=1.01-4.28)$ が確認された. Hosmer-Lemeshow 検定結果は $P=0.122$ で適合して いた（表 3）.

\section{考 察}

今回の研究に参加した静岡県 $\mathrm{A}$ 市在住ブラジル人 生徒の半数以上は長時間に渡ってインターネットを使 用していた。静岡県 A 市在住ブラジル人生徒のイン ターネット依存傾向の割合は日本人生徒やブラジル本 国の生徒といった社会的多数派に関する結果よりも高 かった，更に，インターネット依存傾向が睡眠時間の 減少，インターネット利用時間や高いうつ傾向と関連 することも確認され, 教育・医療現場において注視す べき問題である事も示した.

在日ブラジル人生徒でインターネット依存傾向が高 かった原因について, 考察する. 1 点目に, 言語的障壁 が挙げられる. 先行文献で $28.8 \%$ のブラジル人生徒が 日本語よりもポルトガル語の方が得意, $50.3 \%$ がポル トガル語しか話せないと答えており生徒の一部に言語 
表 3 インターネット依存度との関連要因

\begin{tabular}{|c|c|c|c|c|c|c|c|c|c|c|c|c|c|c|}
\hline \multirow{3}{*}{ 年齢 } & \multirow{3}{*}{$\begin{array}{c}\begin{array}{l}\text { IAT50 } \\
\text { 点未満 }\end{array} \\
N \%\end{array}$} & \multirow{2}{*}{$\begin{array}{c}\text { IAT50 } \\
\text { 点以上 } \\
N \%\end{array}$} & \multicolumn{4}{|c|}{ 単変量解析 } & \multicolumn{2}{|c|}{ 多変量解析 } & \multicolumn{2}{|c|}{ モデル $1 \%$} & \multicolumn{2}{|c|}{ 多変量解析 } & \multicolumn{2}{|c|}{ モデル 2※※ } \\
\hline & & & \multirow[t]{2}{*}{$P$ 值 } & \multirow[t]{2}{*}{$\begin{array}{c}\text { Crude } \\
\text { OR }\end{array}$} & \multicolumn{2}{|c|}{$95 \% \mathrm{Cl}$} & \multirow{4}{*}{$\begin{array}{c}P \text { 值 } \\
0.652\end{array}$} & \multirow{2}{*}{$\begin{array}{c}\text { Adjusted } \\
\text { OR }\end{array}$} & \multicolumn{2}{|c|}{$95 \% \mathrm{Cl}$} & \multirow[t]{2}{*}{$P$ 值 } & \multirow[t]{2}{*}{$\begin{array}{c}\text { Adjusted } \\
\text { OR }\end{array}$} & \multicolumn{2}{|c|}{$95 \% \mathrm{Cl}$} \\
\hline & & & & & & & & & & & & & & \\
\hline 15 歳 & 52 & 19 & & 1 & & & & 1 & & & & 1 & & \\
\hline $\begin{array}{l}\text { 以下 } \\
15 \text { 歳 } \\
\text { 以上 }\end{array}$ & $\begin{array}{c}37.7 \% \\
86 \\
62.3 \% \\
\end{array}$ & $\begin{array}{c}27.5 \% \\
50 \\
72.5 \%\end{array}$ & 0.149 & 1.591 & 0.847 & 2.989 & & 1.260 & 0.534 & 2.724 & 0.711 & 1.159 & 0.531 & 2.528 \\
\hline \multicolumn{15}{|l|}{ 性別 } \\
\hline 女 & $\begin{array}{c}79 \\
52.7 \% \\
71 \\
47.3 \%\end{array}$ & $\begin{array}{c}32 \\
44.4 \% \\
40 \\
55.6 \%\end{array}$ & 0.252 & 1.391 & 0.791 & 2.446 & 0.113 & 1.757 & 0.876 & 3.525 & 0.130 & 1.676 & 0.859 & 3.270 \\
\hline \multicolumn{15}{|l|}{ 日系世代 } \\
\hline $\begin{array}{l}\text { 3世末満 } \\
\text { 3世以上 }\end{array}$ & $\begin{array}{c}14 \\
9.7 \% \\
130 \\
90.3 \% \\
\end{array}$ & $\begin{array}{c}5 \\
7.1 \% \\
65 \\
92.9 \% \\
\end{array}$ & 0.535 & 1.400 & 0.483 & 4.056 & - & $\begin{array}{l}- \\
-\end{array}$ & $\begin{array}{l}- \\
-\end{array}$ & $\begin{array}{l}- \\
-\end{array}$ & - & - & $\begin{array}{l}- \\
-\end{array}$ & $\begin{array}{l}- \\
-\end{array}$ \\
\hline \multicolumn{15}{|c|}{ 日本帯在年数 } \\
\hline $\begin{array}{l}5 \text { 年末満 } \\
5 \text { 年以上 }\end{array}$ & $\begin{array}{c}59 \\
39.9 \% \\
89 \\
60.1 \% \\
\end{array}$ & $\begin{array}{c}25 \\
35.7 \% \\
45 \\
64.3 \% \\
\end{array}$ & 0.557 & 1.193 & 0.662 & 2.151 & 一 & $\begin{array}{l}- \\
-\end{array}$ & $\begin{array}{l}- \\
-\end{array}$ & $\begin{array}{l}- \\
-\end{array}$ & - & $\begin{array}{l}- \\
-\end{array}$ & $\begin{array}{l}- \\
-\end{array}$ & $\begin{array}{l}- \\
-\end{array}$ \\
\hline \multicolumn{15}{|c|}{ 兄弟の有無 } \\
\hline 無 & $\begin{array}{c}51 \\
34.0 \% \\
99 \\
66.0 \% \\
\end{array}$ & $\begin{array}{c}31 \\
43.1 \% \\
41 \\
56.9 \% \\
\end{array}$ & 0.192 & 0.681 & 0.383 & 1.212 & 0.098 & 0.543 & 0.263 & 1.119 & - & $\begin{array}{l}- \\
-\end{array}$ & $\begin{array}{l}- \\
-\end{array}$ & $\begin{array}{l}- \\
-\end{array}$ \\
\hline \multicolumn{15}{|c|}{ クラブ活動の所属 } \\
\hline 無 & $\begin{array}{c}85 \\
56.7 \% \\
65 \\
43.3 \% \\
\end{array}$ & $\begin{array}{c}49 \\
68.1 \% \\
23 \\
31.9 \% \\
\end{array}$ & 0.106 & 0.614 & 0.34 & 1.109 & 0.460 & 0.757 & 0.361 & 1.585 & - & - & - & - \\
\hline \multicolumn{15}{|l|}{ 学外学習 } \\
\hline 無 & $\begin{array}{c}83 \\
55.7 \% \\
66 \\
44.3 \% \\
\end{array}$ & $\begin{array}{c}45 \\
62.5 \% \\
27 \\
37.5 \% \\
\end{array}$ & 0.338 & 0.755 & 0.424 & 1.343 & - & - & - & - & - & - & - & - \\
\hline \multicolumn{15}{|c|}{ スマートフォンの利用 } \\
\hline $\begin{array}{l}\text { 無し } \\
\text { 有り }\end{array}$ & $\begin{array}{c}28 \\
18.7 \% \\
122 \\
81.3 \% \\
\end{array}$ & $\begin{array}{c}14 \\
19.4 \% \\
58 \\
80.6 \% \\
\end{array}$ & 0.890 & 0.951 & 0.466 & 1.941 & 一 & - & - & - & 一 & - & - & - \\
\hline \multicolumn{15}{|c|}{ 動画音楽サイトの利用 } \\
\hline 無し & $\begin{array}{c}15 \\
10.0 \% \\
135 \\
90.0 \% \\
\end{array}$ & $\begin{array}{c}5 \\
6.9 \% \\
67 \\
93.1 \% \\
\end{array}$ & 0.459 & 1.489 & 0.519 & 4.270 & - & - & - & - & - & - & - & - \\
\hline
\end{tabular}


表 3 インターネット依存度との関連要因（続き）

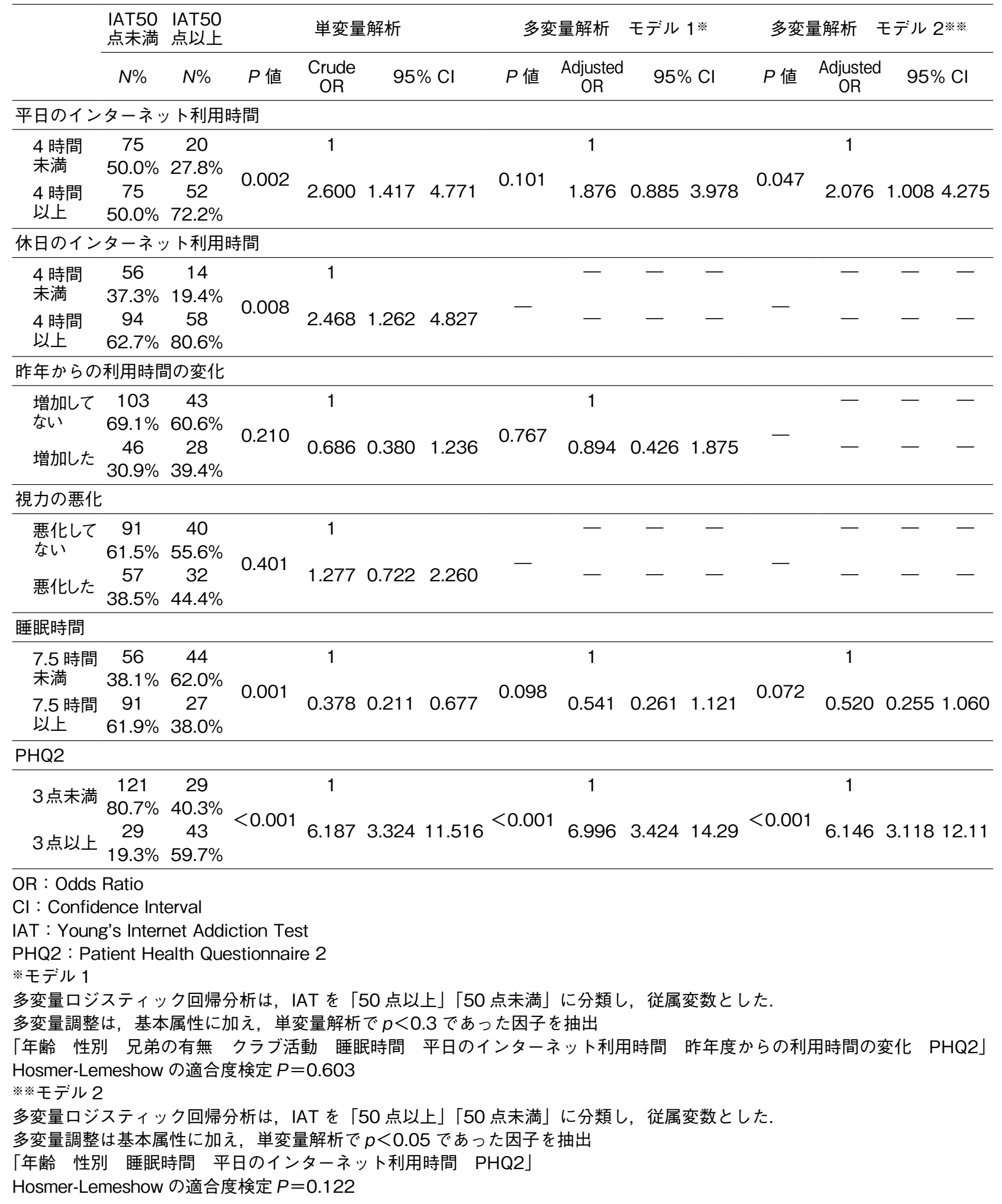


の障壁があることが示されている222．日本社会におい て稀少であるポルトガル語のメデイアに触れたり, 学 業や生活に必要な情報を得たりする為に, インター ネットを積極的に使用している可能性がある ${ }^{35.36)}$.ま た，本研究で動画音楽サイトの使用率が $84.7 \%$ を占め た事から (表 1), 情報メディアとして既に必要不可欠 なインフラになっている可能性がある. 2 点目に社会 との希薄な繋がりが挙げられる. 外国人学校の生徒は 広範囲な地域から送迎を利用して通学するため, 居住 する地域で孤立するリスクがある．静岡県民が外国人 に対して「親しみを感じる」と答えた割合は高いとい えず77.38, ,ブラジル人生徒から歩み寄る難しさが考えら れる.更にブラジル人同士のネットワークにおいても， 入れ替わりが早く信頼関係が築きにくかったり ${ }^{377}$, ネットワークが機能しなくなった場合, むしろ孤立感 が強まったりする構図も指摘されている ${ }^{39.40}$. 先行研究 では社会との繋がりを得るために，社会的マイノリ ティはSNSを使用していると報告されている ${ }^{41 \sim 43)}$. 本 研究でSNS の使用が 2 番目の $74.3 \%$ を占めた事より, 一部の生徒はSNS を活用しインターネット上のコ ミュニティに参加している可能性がある. 3 点目にイ ンターネット依存傾向に対して予防や対策が不十分で ある可能性がある. 生徒を取り巻く環境として, 学校 によっては半日登校を採用しておりり教師や親の目 が届かない時間がある。親子間でのコミュニケーショ ン不足，家族の長時間労働や夜勤労働，ブラジルと日 本を行き来する特殊な生活様式等により, 親が教育に 十分参加できていない背景もあり得る27.44, 45).

以上よりブラジル人生徒は, インターネットを積極 的に使用する環境, もしくは予防や対策が不十分な環 境にあるため, インターネット依存傾向にある可能性 が考察される。

次に, インターネット依存傾向に関連する要因とし て, 最終モデルにおける睡眠時間の関与について考察 する.最終モデルでは, うつ傾向と平日のインターネッ 卜利用時間が有意であったが，睡眠時間の関連につい ては有意ではないものの $P<0.10$ を示した(表 3). 先 行研究で睡眠時間はインターネット依存傾向, うつ傾 向の因子と有意な相関のある因子として報告されてお $り^{10.11)}$, これらの因子は相互に影響するものと考えられ る.インターネット利用時間と睡眠時間の関連につい ては，スマートフォン利用の増大によって生活習慣の 中で睡眠時間が最も削減される (40.7\%) との報告があ る ${ }^{9}$. 本研究でも在日ブラジル人生徒のインターネット 利用時間は日本人生徒と比較して長い傾向にあり, 睡
眠時間の減少に影響している可能性がある. 以上より, 睡眠時間の低下が多変量ロジスティック回帰分析の最 終モデルに抒いて関与したのではないかと考察され る.

本調査は横断研究であることから, 因果関係は推定 に止まる。インターネット依存度拈よびインターネッ 卜利用時間ともに自己申告であって, 臨床医による診 断や客観的評価ではない，対象者の日本語能力を評価 していないため言語障壁は先行文献からの推定に止ま る. 更に, 回答率は $65 \%$ と高くはなく, 低下の要因に 自宅回答としたことが挙げられる。また，関心の高い 親や生徒が中心に回答し, 対象者の偏りを生んだ可能 性がある。しかし，保護者の了承を得て提出ができた 生徒は, 親子間のコミュニケーションや保護者の教育 介入がある，リスクの低い生徒とも推測される，その 為, 偏りがあったとしても本研究結果は実際より過小 評価である可能性が考えられ, 在日ブラジル人生徒の インターネット依存傾向が日本人生徒よりも高いとす る本結果を覆すものではないと考えられる。

本研究では, 社会的マイノリティである在日ブラジ ル人生徒を対象として, インターネット依存傾向のリ スク及びうつ傾向との相関を示した. インターネット に賴らざるを得ない社会的背景を踏まえ, 教育や医療 の現場において課題認識を広める必要がある。 また海 外のプライマリ・ケア領域では, インターネット依存 傾向に対して適切な睡眠や運動, 食事へのアプローチ や専門家への紹介といった介入が提案されており ${ }^{46,47}$, 日本のプライマリ・ケア領域に扔いても今後予防拈よ び解決策の検討を行っていく必要があると考えられ る.

\section{謝 辞}

本研究にご協力いただいた参加者の皆様, 学校関係 者・保護者の皆様，そして統計解析を実施するにあた り有益なご指導を頂いた岡田栄作先生（浜松医科大学 医学部健康社会医学講座）に心からの感謝の意を表す る.

\section{利益相反}

利益相反に相当する事項はない.

\section{文 献}

1）内閣府. 平成 30 年度青少年のインターネット利用環境実 態調查. 東京 : 内閣府; March 2019. [not revised; cited 9 
July 2019]. Available from: https://www8.cao.go.jp/yout h/youth-harm/chousa/h30/net-jittai/pdf/kekka_gaiyo.p df

2）総務省, 情報通信政策研究所. 中学生のインターネットの 利用状況と依存傾向に関する調查. 東京：総務省； June 2016. [not revised; cited 9 July 2019]. Available from: htt p://www.soumu.go.jp/iicp/chousakenkyu/data/researc h/survey/telecom/2016/20160630_02.pdf

3) Machado MR, Bruck I, Antoniuk SA, et al. Internet addiction and its correlation with behavioral problems and functional impairments-Across-sectional study. J Bras Psiquiatr. 2018; $67(1)$ : 34-38. doi : $10.1590 / 0047-$ 2085000000181

4) Lee HK. Effects of individual- and social-related factors and motives for game playing on game concentration and game addiction. Korean Journal of Youth Studies. 2003; 10: 355-380

5) Ha JH, Kim SY, Bae SC, et al. Depression and internet addiction in adolescents. Psychopathology. 2007; 40(6): 424430.

6) Yoo HJ, Cho SH, Ha J, et al. Attention deficit hyperactivity symptoms and internet addiction. Psychiatry Clin Neurosci. 2004; 58(5): 487-494.

7) Huang $\mathrm{AC}$, Chen HE, Wang YC, et al. Internet abusers associate with a depressive state but not a depressive trait. Psychiatry Clin Neurosci. 2014; 68(3): 197-205. doi: 10.1111/pcn.12124.

8）成順月, 原ひろみ, 鮎川昌代. 思春期のメンタルヘルス問 題がインターネット依存傾向に与える影響. 小児保健研 究. $2017 ; 76$ (6) : 608-617.

9）総務省, 情報通信政策研究所. 高校生のスマートフォン • アプリ利用とネット依存傾向に関する調查報告書. 東 京: 総 務 省 ; June 2014. [not revised; cited 9 July 2019]. Available from: http://www.soumu.go.jp/menu_news/snews/01iicp01_02000020.html

10) Bhandari PM, Neupane D, Rijal S, et al. Sleep quality, internet addiction and depressive symptoms among undergraduate students in Nepal. BMC Psychiatry. 2017; 17: 106-113. doi: 10.1186/s12888-017-1275-5.

11) Li JB, Lau JTF, Mo PKH, et al. Insomnia partially mediated the association between problematic Internet use and depression among secondary school students in China. J Behav Addict. 2017; 6(4): 554-563. doi: 10.1556/ 2006.6.2017.085

12) Elias N, Lemish D. Spinning the web of identity: the roles of the internet in the lives of immigrant adolescents. New Media \& Society. 2009; 11(4): 533-551. doi: 10.1177/ 1461444809102959.

13) Rumpf HJ, Vermulst AA, Bischof A, et al. Occurence of internet addiction in a general population sample: a latent class analysis. Eur Addict Res. 2014; 20(4): 159-166. doi: 10.1159/000354321.

14) Campisi L, Berchtold A, Barrense-Dias Y, et al. Risk behaviours among native and immigrant youths in Switzerland: a cross-sectional study. Swiss Med Wkly. 2017; 147: w14531. doi: 10.4414/smw.2017.14531.

15) Straiton M, Reneflot A, Diaz E. Immigrants' use of pri- mary health care services for mental health problems. BMC Health Serv Res. 2014; 14: 341. doi: 10.1186/14726963-14-341.

16) McWhinney IR, Freeman TR. Textbook of Family Medicine. 3rd ed. Oxford University Press, Inc; 2009. 163.

17）法務省. 令和元年 6 月末現在における在留外国人数につ いて（速報值）。東京：法務省； 25 October 2019. [not revised; cited 21 December 2019]. Available from: http://w ww.moj.go.jp/nyuukokukanri/kouhou/nyuukokukanri04 _00083.html

18）法務省. 平成 30 年末現在に抒ける在留外国人数につい て：【平成 30 年末】公表資料 p5-6. 東京 : 法務省 ; 22 March 2019. [not revised; cited 4 August 2019]. Available from: http://www.moj.go.jp/nyuukokukanri/kouhou/ny uukokukanri04_00081.html

19）静岡県. 外国人登録国籍別市町村別人員調査（平成 29 年末現在). 静岡 : 知事直轄組織多文化共生課 ; 23 October 2018. [not revised; cited 9 July 2019]. Available from: https://toukei.pref.shizuoka.jp/tabunkakyouseika/data/ 02-050/2017gaikokujin.html

20）文部科学省. 外国人学校の現状について. 東京 : 文部科学 省； [not revised; cited 21 December 2019]. Available from: https://www.mext.go.jp/b_menu/shingi/chukyo/c hukyo3/siryo/06070415/005.htm

21）文部科学省. 我が国において, 高等学校相当として指定し た外国人学校一覧 (平成 31 年 3 月 28 日現在). 東京 : 文 部科学省 ; 28 March 2019. [not revised; cited 21 December 2019]. Available from: https://www.mext.go.jp/a_me nu/koutou/shikaku/07111314/003.htm

22）濱田国佑. ブラジル人学校の児童・生徒と保護者の意識. 調査と社会理論・研究報告書. $2008 ; 25: 140$.

23) Young KS. Caught in the Net: How to recognize the signs of Internet addiction and a winning strategy for recovery. New York: John Wiley \& Sons; 1998.

24) Conti MA, Jardim AP, Hearst N, et al. Evaluation of semantic equivalence and internal consistency of a Portuguese version of the Internet Addiction Test (IAT). Rev Psiq Clin. 2012; 39(3): 106-110. doi: 10.1590/S010160832012000300007.

25）大塚公一郎, 宮坂リンコン, 辻恵介, 他. 在日日系ブラジ ル人の精神医学的調査. 日社精医誌. $1998 ; 7(2) ： 165-$ 172.

26）河邊憲太郎, 堀内史枝, 越智麻里奈, 他. 青少年における インターネット依存の有病率と精神的健康状態との関 連. 精神神経学雑誌. $2017 ； 119$ (9)：613-620.

27）近藤州, 大塚公一朗, 沢口グラウシア, 他. 日本に在住す る日系ブラジル人児童・生徒のメンタルヘルスの現状-ブ ラジル在住の日系人児童・生徒との比較調査より-. 日社 精医誌. $2009 ； 18$ (1) : 105-111.

28) Pfizer Inc. Patient Health Questionnaire (PHQ) Screeners. Pfizer Inc. [not revised; cited 26 July 2018]. Available from: http://www.phqscreeners.com

29) Kroenke K, Spitzer RL, Williams JB. The Patient Health Questionnaire-2 : validity of a two-item depression screener. Med Care. 2003; 41(11): 1284-1292. doi: 10.1097/ 01.MLR.0000093487.78664.3C.

30) Arroll B, Goodyear-Smith F, Crengle S, et al. Validation of 
PHQ-2 and PHQ-9 to Screen for Major Depression in the Primary Care Population. Ann Fam Med. 2010; 8: 348-353. doi: 10.1370/afm.1139.

31) Banjanin N, Banjanin N, Dimitrijevic I, et al. Relationship between internet use and depression: Focus on physiological mood oscillations, social networking and online addictive behavior. Computers in Human Behavior. 2015; 43: 308-312. doi: 10.1016/j.chb.2014.11.013.

32) Yoo HJ, Cho SC, Ha J, et al. Attention deficit hyperactivity symptoms and Internet addiction. Psychiatry and Clinical Neurosciences. 2004; 58: 487-494. doi: 10.1111/ j.1440-1819.2004.01290.x.

33) Alavi SS, Maracy MR, Jannatifard F, et al. The effect of psychiatric symptoms on the internet addiction disorder in Isfahan's University students. J Res Med Sci. 2011; 16 (6): 793-800.

34) Tateno M, Teo AR, Shiraishi M, et al. Prevalence rate of Internet addiction among Japanese college students: Two cross - sectional studies and reconsideration of cut - off points of Young's Internet Addiction Test in Japan. Psychiatry and Clinical Neurosciences. 2018; 72(9): 723-730. doi: 10.1111/pcn.12686.

35）重松由美. 在日ブラジル人高校生・大学生の言語生活と アイデンティティ. 椙山女学園大学教育学部紀要. 2012 ; $5: 63$.

36）アンジェロイシ。在住外国人への広報〜在日ブラジル人 の事例を中心に. 国際文化研修 2010 秋. $2010 ； 69 ： 23-24$.

37）池上重弘. 静岡県に扔ける多文化共生に関する 2 つの基 礎調査の詳細分析報告書 : 2016 年の静岡県調査と 2015 年の磐田市調查から 18 . 浜松市 : 静岡文化芸術大学 ; September 2010. [not revised; cited 9 July 2019]. Available from: http://id.nii.ac.jp/1132/00000793/

38）池上重弘. アンケート結果から見える多文化共生の最前 線: 静岡県多文化共生基礎調查 2016 の詳細分析報告会 報告 2 日本人調查から見える多文化共生意識の変容. 浜 松市: 静岡文化芸術大学; October 2017. [not revised; cited 9 July 2019]. Available from: http://id.nii.ac.jp/1132/ 00001367/

39）浜松市精神保健福祉センター. 経済状況の変化とこころ の健康に関するアンケート調查報告書 : 浜松市における
外国人市民のメンタルヘルス実態調査 $\mathrm{p} 46$. 浜松市 : 浜 松市精神保健福祉センター; September 2010. [not revised; cited 22 November 2019]. Available from: https://s uac.repo.nii.ac.jp $/$ ?action=repository_uri\&item_id $=816 \& f$ ile_id $=19 \&$ file_no $=8$

40）浜松市精神保健福祉センター．経済状況の変化とこころ の健康に関するアンケート調查報告書 : 浜松市における 外国人市民のメンタルヘルス実態調查 p71-72. 浜松市 : 浜松市精神保健福祉センター; September 2010. [not revised; cited 22 November 2019]. Available from: https://s uac.repo.nii.ac.jp/?action=repository_uri\&item_id $=816 \& f$ ile_id $=19 \&$ file_no $=9$

41) Lee SK, Katz JE. Bounded Solidarity Confirmed? How Korean Immigrants' Mobile Communication Configures Their Social Networks. Journal of Computer-Mediated Communication. 2015; 20: 615-631. doi: 10.1111/jcc4.12142.

42) Damian E, van Ingen E. Social Network Site Usage and Personal Relations of Migrants. Societies. 2014; 4: 640-653. doi: 10.3390/soc4040640.

43) Ye J. Traditional and Online Support Networks in the Cross-Cultural Adaptation of Chinese International Students in the United States. Journal of ComputerMediated Communication. 2006; 11(3): 863-876. doi: 10.1111/j.1083-6101.2006.00039.x.

44）谷㴊真也, 高田純, 兒玉憲一. 不登校の滞日日系ブラジル 人児童生徒の親子関係及び親子のニーズに関する質的検 討. 心理相談センター紀要. $2015 ；(11) ： 7-12$.

45）浜松市精神保健福祉センター. 経済状況の変化とこころ の健康に関するアンケート調査報告書 : 浜松市における 外国人市民のメンタルヘルス実態調査 $\mathrm{p} 21$. 浜松市 : 浜 松市精神保健福祉センター; September 2010. [not revised; cited 9 July 2019]. Available from: http://id.nii.ac.j $\mathrm{p} / 1132 / 00000793 /$

46) Loton DJ, Lubman DI. Just one more level: Identifying and addressing internet gaming disorder within primary care. Aust Fam Physician. 2016; 45(1): 48-52.

47) Prabhakaran MC, Patel VR, Ganjiwale DJ, et al. Factors associated with internet addiction among school-going adolescents in Vadodara. J Family Med Prim Care. 2016; 5(4): 765-769. doi: 10.4103/2249-4863.201149. 